\title{
The Family Purchasing Decision: A Field Study On Monthly Grocery Expenses Of Turkish Families In Ankara, Turkey
}

Elif Akagün Ergin, (E-mail: eakagun@ @ankaya.edu.tr), Çankaya University, Turkey Handan Özdemir, (E-mail: h_ozdemir@ cankaya.edu.tr), Çankaya University, Turkey Bülent Özsaçmacı, (E-mail: bozsacmaci@ cankaya.edu.tr),Çankaya University, Turkey

\begin{abstract}
It is crucial for companies to find out relevant information about the purchasing agents within families since they play a great role in the shaping of marketing, sales and promotion strategies of a company. This article consists of two parts. In the theoretical part, information about consumer buying behavior and purchasing decisions of families, turkish in particular, is presented. In the applications part of the study, surveys are conducted to married couples living in 10 different districts in Ankara, Turkey to determine the purchasing agents for the monthly grocery expenses of these families. This article will provide turkish and foreign companies the opportunity to understand their target markets better and carry out specific market research and promotional activities aimed at them. In addition, these companies will be in a better position to predict how their consumers will respond to marketing strategies.
\end{abstract}

\section{INTRODUCTION}

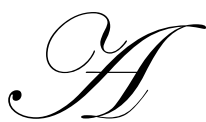

company's ability to maintain satisfying customer relationships requires an understanding of consumer buying behavior. This refers to the buying behavior of consumers who purchase products for their personal or household use. Consumers have limited time, energy and financial resources. Within the limits of these available resources, they make purchase and consumption choices as they wish.

Consumers purchasing decisions take place over a period of time. The overall goal during this decision process is to evaluate various alternatives and choose the product that satisfies the consumer in an optimal way. Consumers get influenced by several major factors while they make their decisions. These factors can be grouped as social, cultural, pscyhological, and personal factors( Kotler \& Armstrong, 1997: 141).

Consumers try to purchase and maintain a variety of products that satisfy their current and future needs. Therefore, they engage in problem solving processes. People purchase products such as books, clothing, education and transportation. Due to the nature of these products, they engage in different types of problem solving processes. The consumer's degree of interest in a product and the importance s/he places on this product determines this consumer's level of involvement. High-involvement products are usually expensive and are visible to other people such as a Donna Karan suit or a BMW car. Low-involvement products are less expensive and have less social risk associated with them such as a cup of coffee or a copy of Wall Street Journal. Consumers use three different types of problem solving processes. When buying frequently purchased, low-cost items that require very little search and decision effort, they use routinized response behavior. When buying products occasionally or when they need to get information about an unfamiliar brand in a familiar product category, they use limited problem solving. When they buy unfamiliar, expensive products, they use extended problem solving. 
Mostly, consumers go through a 5-stage decision process. The first stage, problem recognition, takes place when a buyer becomes aware of a desired state and an actual condition. After realizing this need, consumers move on to the second stage to search for information. This information search leads to evaluation of alternatives where a consumer carefully analyzes the available choices. In the purchase stage, the consumer chooses the product to be bought. Following the purchase, consumers begin to evaluate the product in the post purchase evaluation.

\section{PURCHASING DECISION IN THE FAMILY: WHO MAKES IT?}

A critical issue for marketers is to find out who the purchasing agent in the family is. The answer to this particular question depends on several factors such as the roles of family members, the economic well-being of the family, the number of children and the nature of product to be bought. Prior research in this area has found that mothers make the purchasing decisions for monthly food expenditures of the family however, fathers carry out the act of purchasing.

The woman's influence in the purchasing decision of the family depends on her economic independence. Numerous studies have indicated that fathers make the purchasing decisions in a family where the mother does not work. Other factors that may come into play in this issue include the education level of the family members, income level, and the location of their residence.

One of Turkey's biggest grocery store chains, Gima, recently conducted a "Supermarket Consumer Segmentation" study to determine the purchasing agents in typical Turkish families. The results of this study showed that the purchasing decision in the supermarket is made by $68 \%$ women and $32 \%$ men. (http://www.capital.com.tr/ c/0211/karar.asp) Promotional activities such as commercials, new product development efforts, packaging, pricing \&distribution strategies all play a significant role in determining the person that makes the purchasing decision in the family.

\section{PURPOSE OF THE STUDY}

This study aims to identify the purchasing agents of monthly grocery expenses of families living in the local districts of Ankara, Turkey. The main goal is to determine the most influential person in the family during the purchasing decision process and to discover whether this influence is related to factors such as the person's age, gender, monthly salary, the role s/he plays in the family, the number of employed people within the household, the district they live in or the number of children they have.

\section{DETERMINING THE SAMPLE SIZE}

Ankara has 25 local districts but for this study, 10 of these districts have been selected through the random sampling method. Sample size was 382 people and the selected districts included Yenimahalle, Etimesgut, Cubuk, Ayas, Kizilcahamam, Akyurt, Cankaya, Bala, Evren and Golbasi. Surveys were distributed to the married couples living in these particular districts. Out of the 382 surveys, 314 were completed, returned and included in the study. The overall response rate was $\% 82$.

\section{METHOD}

A survey composed of 17 questions was used to gather data. The first 10 questions and question 18 were strictly demographic whereas questions 11 through 16 were specially targeted for main research points of the study.

Prior to conducting the field study, the validity of the survey questions was assessed through a pilot study including a group of 30 people. After the surveys were conducted on all the participants, that data on the survey forms were coded and entered into the computer. The coded data was sorted and analyzed by SPSS program. Chisquare technique was used for this analysis. 
The hypotheses of the study are as follows:

H0: The purchasing decision of a family's monthly grocery expenses is not made by the mother.

H1: The purchasing decision of a family's monthly grocery expenses is made by the mother.

H 01: There is no relationship between the person who makes the monthly grocery purchasing decision and the gender.

H 02: There is no relationship between the person who makes the monthly grocery purchasing decision and the age.

H 03: There is no relationship between the person who makes the monthly grocery purchasing decision and the education level.

H 04: There is no relationship between the person who makes the monthly grocery purchasing decision and the district that person lives.

H 05: There is no relationship between the person who makes the monthly grocery purchasing decision and the number of employed people in the household.

H 06: There is no relationship between the person who makes the monthly grocery purchasing decision and the number of children in the family.

H 07: There is no relationship between the person who makes the monthly grocery purchasing decision and the marriage duration of the couples.

H 08: There is no relationship between the person who makes the monthly grocery purchasing decision and the level of income.

H 09: There is no relationship between the person who makes the monthly grocery purchasing decision and who makes the purchase.

H 10: There is no relationship between the person who makes the monthly grocery purchasing decision and who makes purchasing Decisions.

\section{FINDINGS OF THE RESEARCH}

The findings are explored below based on the data gathered.

\subsection{Allocation Of The Test Subjects According To The Gender Issue}

According to the Table-1, we can observe that the female test subjects have a greater population than the male ones. After the result of the analysis, 53,2 percent of the test subjects are composed of females and the 46,5 percent of the test subjects are composed of the males.

Table 1. Allocation of the Experiment Group According to the Gender Issue

\begin{tabular}{|c||c||c||}
\hline Gender & Number of the Test Subjects & Percentage Value \\
\hline \hline Female & 168 & 53,2 \\
\hline \hline Male & 146 & 46,5 \\
\hline \hline Total & 314 & 100,0 \\
\hline
\end{tabular}




\subsection{Allocation of the Test Subjects According to the Age Groups}

Table-2 lists the age groups of the test subjects who took the survey. According to this allocation, the 0,6 percent of the test subjects are in 16-20 age group, the 9,6 percent of the subjects are in 21-25 age group, the 14,3 percent of the subjects are in 26-30 age group, 5,6 percent of the subjects are in 31-35 age group, the 19,1 percent of the subjects are in 36-40 age group, and finally the 40,8 percent of the subjects are in 41 and older age group.

Table 2. Allocation of the Test Subjects According to the Age Groups

\begin{tabular}{|c||c||c|}
\hline Age Group & Number of the Test Subjects & Percentage Value \\
\hline \hline $\mathbf{1 6 - 2 0}$ & 2 & 0,6 \\
\hline $\mathbf{2 1 - 2 5}$ & 30 & 9,6 \\
\hline $\mathbf{2 6 - 3 0}$ & 45 & 14,3 \\
\hline $\mathbf{3 1 - 3 5}$ & 49 & 15,6 \\
\hline \hline $\mathbf{3 6 - 4 0}$ & 60 & 19,1 \\
\hline \hline 41 and older & 128 & 40,8 \\
\hline \hline Total & 314 & 100,0 \\
\hline
\end{tabular}

\subsection{Allocation of the Test Subjects According to the Education Level}

Table 3 shows the test subjects according to their education level. According to this allocation; the 13,7 percent of the test subjects have a Primary School degree, 9,9 percent have a Secondary-School degree, 30,3 percent have a High School Degree, 39,2 percent have a University Degree, 6,7 percent have a Master Degree and finally 0,3 percent of the test subjects are illiterate.

Table 3. Allocation of the Test Subjects According to the Education Level

\begin{tabular}{|c||c||c||}
\hline Education Level & Number of the Test Subjects & Percentage Value \\
\hline \hline Primary School Degree & 43 & 13,7 \\
\hline \hline Secondary School Degree & 31 & 9,9 \\
\hline \hline High School Degree & 95 & 30,3 \\
\hline University Degree & 123 & 39,2 \\
\hline \hline Master Degree & 21 & 6,7 \\
\hline \hline Do not know reading\&writing & 1 & 0,3 \\
\hline Total & 314 & 100,0 \\
\hline
\end{tabular}

\subsection{Allocation of the Test Subjects According to the Districts Where They Live}

Allocation of the test subjects are presented in Table 4 according to the districts where they live. Allocations are made according to the Proportional Sampling Method. By this method the district population is proportioned to the sample size and the results are listed as; the 33,4 percent of the test subjects are living in Yenimahalle, 44,3 percent are living in Çankaya, 7 percent are living in Etimesgut, 2,2 percent living in Çubuk, 1,3 percent are living in Ayaş, 1,3 percent are living in Akyurt, 2,5 percent are living in Bala, 0,6 percent are living in Evren, 5,1 percent are living in Gölbaşı and 2,2 percent of the test subjects are living in Kızılcahamam. 
Table 4. Allocation of the Test Subjects According to the Districts Where They Live

\begin{tabular}{|c||c|c||}
\hline \multicolumn{1}{|c|}{ Districts } & Number of the Test Subject & Percentage Value \\
\hline Yenimahalle & 105 & 33,4 \\
\hline Çankaya & 139 & 44,3 \\
\hline Etimesgut & 22 & 7,0 \\
\hline Çubuk & 7 & 2,2 \\
\hline Ayaş & 4 & 1,3 \\
\hline Akyurt & 4 & 1,3 \\
\hline Bala & 8 & 2,5 \\
\hline Evren & 2 & 0,6 \\
\hline Gölbaşı & 16 & 5,1 \\
\hline Kuzlcahamam & 7 & 2,2 \\
\hline Toplam & 314 & 100,0 \\
\hline
\end{tabular}

\subsection{Allocation of the Test Subjects According to the Jop Groups}

Test subjects are grouped according to their job groups in Table 5. According to the survey results, the 3,5 percent of the test subjects are doctors, 2,4 percent are lawyers, 6,4 percent are engineers, 19,4 percent are housewives, 16,2 percent are government officials, 6,4 percent are retired, 5,7 percent are teachers, 17,5 percent are self-employed, 2,5 percent are academicians, 8 percent are employees, 1 percent are architects, and 1,6 percent are pharmacists. The 9,2 percent of the group define their jobs as, accountants, insurane reps, bankers and journalists.

Table 5. Allocation of the Test Subjects According to the Jop Groups

\begin{tabular}{||c||c||c||}
\hline \multicolumn{1}{|c||}{ Jobs } & Number Of The Test Subjects & Percentage Value \\
\hline \hline Doctor & 11 & 3,5 \\
\hline \hline Lawyer & 8 & 2,4 \\
\hline \hline Engineer & 20 & 6,4 \\
\hline \hline House Wife & 61 & 19,4 \\
\hline \hline Government Official & 51 & 16,2 \\
\hline \hline Retired & 20 & 6,4 \\
\hline \hline Teacher & 18 & 5,7 \\
\hline \hline Self-Employed & 55 & 17,5 \\
\hline \hline Academic & 8 & 2,5 \\
\hline \hline Employee & 25 & 8,0 \\
\hline \hline Architect & 3 & 1,0 \\
\hline \hline Pharmacist & 5 & 1,6 \\
\hline \hline Other & 29 & 9,2 \\
\hline Total & 314 & 100,0 \\
\hline
\end{tabular}




\subsection{Allocation of the Test Subjects According to the Working Person in the Household}

Allocation of the test subjects are given in Table 6 according to the working person in the household. According to the survey, 57 percent of the test subjects belong to the two person working in a household section. The 34,7 percent belongs to the 1 person working section, 4,8 percent belongs to 3 people working section.

Table 6. Allocation of the Test Subjects According to the Working Person in the Household

\begin{tabular}{|c|c||c||}
\hline $\begin{array}{c}\text { Number of working Person in } \\
\text { the Household }\end{array}$ & Number of the Test Subjects & Percentage Value \\
\hline \hline $\mathbf{1}$ & 109 & 34,7 \\
\hline \hline $\mathbf{2}$ & 179 & 57 \\
\hline \hline $\mathbf{3}$ & 15 & 4,8 \\
\hline \hline $\mathbf{5}$ & 3 & 1 \\
\hline \hline $\mathbf{6}$ & 1 & 0,3 \\
\hline \hline Not Working & 1 & 0,3 \\
\hline \hline Total & 5 & 1,9 \\
\hline \hline
\end{tabular}

\subsection{Allocation of the Test Subjects According to the Number of Children}

Allocation of the test subjects are given in Table 7 according to the number of children in the family. According to the allocation, the 37,6 percent of the families have 2 kids. The 28,7 percent of the couples have one child, 10,5 percent have 3 kids and the 18,5 percent of the families have no kids.

Table 7. Allocation of the Test Subjects According to the Number of Children

\begin{tabular}{|c||c|c||}
\hline Number of Children & Number of the Test Subjects & Percentage Value \\
\hline \hline $\mathbf{1}$ & 90 & 28,7 \\
\hline \hline $\mathbf{2}$ & 118 & 37,6 \\
\hline \hline $\mathbf{4}$ & 33 & 10,5 \\
\hline $\mathbf{5}$ & 9 & 2,9 \\
\hline $\mathbf{7}$ & 5 & 1,6 \\
\hline \hline No Children & 1 & 0,3 \\
\hline \hline Total & 58 & 18,5 \\
\hline \hline
\end{tabular}

\subsection{Allocation of the Test Subjects According to the Marriage Time}

Table 8 lists test subjects according to the duration of the marriage. The 6,7 percent of the couples are newly married. 19,7 percent have been married for 2-5 years, 15,3 percent have been married for 6-10 years, 16,2 percent have been married for 11-15 years, 8,9 percent have been married for 16-20 years, 15,9 percent have been married for 21-25 years and 17,2 percent of the couples have been married for 26 years and above. 
Table 8. Allocation of the Test Subjects According to the Marriage Time

\begin{tabular}{|c||c||c||}
\hline Marriage Time & Number of the Test Subjects & Percentage Value \\
\hline \hline 0-1 Year & 21 & 6,7 \\
\hline \hline $\mathbf{2 - 5}$ Years & 62 & 19,7 \\
\hline \hline $\mathbf{6 - 1 0}$ Years & 48 & 15,3 \\
\hline \hline $\mathbf{1 1 - 1 5}$ Years & 51 & 16,2 \\
\hline \hline $\mathbf{1 6 - 2 0}$ Years & 28 & 8,9 \\
\hline \hline $\mathbf{2 1 - 2 5}$ Years & 50 & 15,9 \\
\hline \hline $\mathbf{2 6}$ and above & 54 & 17,2 \\
\hline Total & 314 & 100,0 \\
\hline
\end{tabular}

\subsection{Allocation of the Test Subjects According to the Average Income Level}

In the research the test subjects' income level have been divided to 5 sections. Based on this, the 6,7 percent of the test subjects have an income level of 100-499 million Turkish Liras., 23,2 percent have 500-999 million, 24,8 percent have 1 billion-1 billion 499 million, 20,1 percent have 1 billion 500 million- 1 billion 999 million and 25,2 percent have an income level of 2 billion and above.

Table 9. Allocation of the Test Subjects According to the Average Income Level

\begin{tabular}{|c||c||c||}
\hline Monthly Income Level (TL) & Number of the Test Subjects & Percentage Value \\
\hline \hline $\mathbf{1 0 0 - 4 9 9}$ million & 21 & 6,7 \\
\hline \hline $\mathbf{5 0 0 - 9 9 9}$ million & 73 & 23,2 \\
\hline \hline 1 billion-1 billion 499 million & 78 & 24,8 \\
\hline \hline $\begin{array}{c}\text { 1 billion 500 million- 1 billion } \\
\text { 999 million }\end{array}$ & 63 & 20,1 \\
\hline \hline 2 billion and above & 79 & 25,2 \\
\hline \hline Total & 314 & 100,0 \\
\hline
\end{tabular}

6.10. Analyzing The Relationship Between The Person Who Makes The Monthly Grocery Purchasing Decision And The Gender

After the analysis for the two variables; ( see Table 10) the probability value $(\alpha=0,05)$ is less than the level of significance. In this situation, we reject the H 01 hypothesis thus; there is a strong relationship between the person who makes the monthly grocery purchasing decision and the gender.

Table 10. Analyzing The Relationship Between The Person Who Makes The Monthly Grocery Purchasing Decision And The Gender

\begin{tabular}{|l|c||c||c||}
\hline $\begin{array}{l}\text { H 01: There is no relationship between the person who } \\
\text { makes the monthly grocery purchasing decision and the gender. }\end{array}$ & $\begin{array}{c}\text { Chi-Square } \\
\text { Value }\end{array}$ & Df & p value \\
\hline $\begin{array}{l}\text { Gender } * \text { The Person Who Makes The Monthly Grocery } \\
\text { Purchasing Decision }\end{array}$ & $13,617^{\mathrm{a}}$ & 3 &, 003 \\
\hline
\end{tabular}




\subsection{Analyzing The Relationship Between The Person Who Makes The Monthly Grocery Purchasing} Decision And The Age

After the analysis for the two variables; (see Table 11) the probability value $(\alpha=0,05)$ is greater than the level of significance. In this situation, we accept the $\mathrm{H} 02$ hypothesis thus; there is no relationship between the person who makes the monthly grocery purchasing decision and the age.

Table 11. Analyzing The Relationship Between The Person Who Makes The Monthly Grocery Purchasing Decision And The Age

\begin{tabular}{|l|c||c|c||}
\hline $\begin{array}{l}\text { H 02: There is no relationship between the person who } \\
\text { makes the monthly grocery purchasing decision and the age. }\end{array}$ & $\begin{array}{c}\text { Chi-Square } \\
\text { Value }\end{array}$ & df & p value \\
\hline $\begin{array}{l}\text { Age * The Person Who Makes The Monthly Grocery } \\
\text { Purchasing Decision }\end{array}$ & $15,607^{\mathrm{a}}$ & 15 &, 409 \\
\hline
\end{tabular}

\subsection{Analyzing The Relationship Between The Person Who Makes The Monthly Grocery Purchasing Decision And The Education Level}

After the analysis for the two variables; (see Table 12) the probability value $(\alpha=0,05)$ is greater than the level of significance. In this situation, we accept the H 03 hypothesis thus; there is no relationship between the person who makes the monthly grocery purchasing decision and the education level.

Table 12. Analyzing The Relationship Between The Person Who Makes The Monthly Grocery Purchasing Decision And The Education Level

\begin{tabular}{|l||c|c|c||}
\hline $\begin{array}{l}\text { H 03: There is no relationship between the person who makes } \\
\text { the monthly grocery purchasing decision and the education level. }\end{array}$ & $\begin{array}{c}\text { Chi-Square } \\
\text { value }\end{array}$ & df & p value \\
\hline \hline $\begin{array}{l}\text { Education Level * The Person Who Makes The Monthly Grocery } \\
\text { Purchasing Decision }\end{array}$ & $22,066^{\mathrm{a}}$ & 15 &, 106 \\
\hline
\end{tabular}

\subsection{Analyzing The Relationship Between The Person Who Makes The Monthly Grocery Purchasing Decision And The Which District That Person Lived}

After the analysis for the two variables; (see Table 13) the probability value $(\alpha=0,05)$ is less than the level of significance. In this situation, we reject the $\mathrm{H} 04$ hypothesis thus; there is a strong relationship between the person who makes the monthly grocery purchasing decision and the which district that person lived.

Table 13. Analyzing The Relationship Between The Person Who Makes The Monthly Grocery Purchasing Decision And The District That Person Lived

\begin{tabular}{|l||c||c||c||}
\hline $\begin{array}{l}\text { H 04: There is no relationship between the person who makes the } \\
\text { monthly grocery purchasing decision and the which district that } \\
\text { person lived. }\end{array}$ & $\begin{array}{c}\text { Chi-Square } \\
\text { value }\end{array}$ & df & p value \\
\hline $\begin{array}{l}\text { District That Person Lived * The Person Who Makes The Monthly } \\
\text { Grocery Purchasing Decision }\end{array}$ & $49,275^{\text {a }}$ & 27 &, 006 \\
\hline
\end{tabular}


6.14. Analyzing The Relationship Between The Person Who Makes The Monthly Grocery Purchasing Decision And The Working Person in the Household

After the analysis for the two variables; (see Table 14) the probability value $(\alpha=0,05)$ is greater than the level of significance. In this situation we accept the H 05 hypothesis thus; there is no relationship between the person who makes the monthly grocery purchasing decision and the working person in the household.

Table 14. Analyzing The Relationship Between The Person Who Makes The Monthly Grocery Purchasing Decision And The Working Person in the Household

\begin{tabular}{|l||c||c||c||}
\hline $\begin{array}{l}\text { H 05: There is no relationship between the person who makes } \\
\text { the monthly grocery purchasing decision and the working person in } \\
\text { the household. }\end{array}$ & $\begin{array}{c}\text { Chi-Square } \\
\text { value }\end{array}$ & df & p value \\
\hline \hline $\begin{array}{c}\text { Working Person İn The Household * The Person Who Makes The } \\
\text { Monthly Grocery Purchasing Decision }\end{array}$ & $14,790^{\mathrm{a}}$ & 18 &, 676 \\
\hline
\end{tabular}

\subsection{Analyzing The Relationship Between The Person Who Makes The Monthly Grocery Purchasing} Decision And The Number of Children in the Family

After the analysis for the two variables; (see Table 15) the probability value $(\alpha=0,05)$ is greater than the level of significance. In this situation we accept the H 06 hypothesis thus; there is no relationship between the person who makes the monthly grocery purchasing decision and the number of the children in the family.

Table 15. Analyzing The Relationship Between The Person Who Makes The Monthly Grocery Purchasing Decision And The Number of Children in the Family

\begin{tabular}{|l|c||c||c||}
\hline $\begin{array}{l}\text { H 06: There is no relationship between the person who makes the } \\
\text { monthly grocery purchasing decision and the number of children in the } \\
\text { family. }\end{array}$ & $\begin{array}{c}\text { Chi-Square } \\
\text { value }\end{array}$ & df & p value \\
\hline $\begin{array}{l}\text { Number of Children } * \text { The Person Who Makes The Monthly Grocery } \\
\text { Purchasing Decision }\end{array}$ & $12,923^{\mathrm{a}}$ & 15 &, 608 \\
\hline
\end{tabular}

6.16. Analyzing The Relationship Between The Person Who Makes The Monthly Grocery Purchasing Decision And The Marriage Duration of the Couples

After the analysis for the two variables; (see Table 16) the probability value $(\alpha=0,05)$ is less than the level of significance. In this situation we reject the

H 06: hypothesis thus; there is a strong relationship between the person who makes the monthly grocery purchasing decision and the marriage duration of the couples.

Table 16. Analyzing The Relationship Between The Person Who Makes The Monthly Grocery Purchasing Decision And The Marriage Duration of the Couples

\begin{tabular}{|l|c|c||c||}
\hline $\begin{array}{l}\text { H 07: There is no relationship between the person who makes the } \\
\text { monthly grocery purchasing decision and the marriage duration of the } \\
\text { couples. }\end{array}$ & $\begin{array}{c}\text { Chi-Square } \\
\text { value }\end{array}$ & df & p value \\
\hline $\begin{array}{l}\text { The Marriage Duration * The Person Who Makes The Monthly } \\
\text { Grocery Purchasing Decision }\end{array}$ & $31,427^{\text {a }}$ & 18 &, 026 \\
\hline
\end{tabular}


6.17. Analyzing The Relationship Between The Person Who Makes The Monthly Grocery Purchasing Decision And The Level of Income

After the analysis for the two variables; (see Table 17) the probability value $(\alpha=0,05)$ is less than the level of significance. In this situation, we reject the $\mathrm{H} 08$ hypothesis thus; there is a strong relationship between the person who makes the monthly grocery purchasing decision and the level of income.

Table 17. Analyzing The Relationship Between The Person Who Makes The Monthly Grocery Purchasing Decision And The Level of Income

\begin{tabular}{|l||c||c||c||}
\hline $\begin{array}{l}\text { H 08: There is no relationship between the person who makes } \\
\text { the monthly grocery purchasing decision and the level of income. }\end{array}$ & $\begin{array}{c}\text { Chi-Square } \\
\text { value }\end{array}$ & df & p value \\
\hline \hline $\begin{array}{l}\text { Level of Income * The Person Who Makes The Monthly Grocery } \\
\text { Purchasing Decision }\end{array}$ & $24,728^{\mathrm{a}}$ & 12 &, 016 \\
\hline
\end{tabular}

\subsection{Analyzing The Relationship Between The Person Who Makes The Monthly Grocery Purchasing Decision And Who Makes The Purchase}

After the analysis for the two variables; (see Table 18 ) the probability value $(\alpha=0,05)$ is less than the level of significance. In this situation, we reject the H 09 hypothesis thus; there is a strong relationship between the person who makes the monthly grocery purchasing decision and the one who actually does the purchasing.

Table 18. Analyzing The Relationship Between The Person Who Makes The Monthly Grocery Purchasing Decision And Who Makes The Purchase

\begin{tabular}{|l||c||c||c||}
\hline $\begin{array}{l}\text { H 09: There is no relationship between the person who makes } \\
\text { the monthly grocery purchasing decision and who makes the } \\
\text { purchase. }\end{array}$ & $\begin{array}{c}\text { Chi-Square } \\
\text { value }\end{array}$ & df & p value \\
\hline $\begin{array}{l}\text { Person Makes the Purchase * The Person Who Makes The Monthly } \\
\text { Grocery Purchasing Decision }\end{array}$ & $112,697^{\mathrm{a}}$ & 9 &, 000 \\
\hline
\end{tabular}

\subsection{Analyzing The Relationship Between The Person Who Makes The Monthly Grocery Purchasing} Decision And The Person Who Makes Purchasing Decisions

After the analysis for the two variables; (see Table 19) the probability value $(\alpha=0,05)$ is less than the level of significance. In this situation, we reject the $\mathrm{H} 10$ hypothesis thus; there is a meaningful relationship between the person who makes the monthly grocery purchasing decision and the person who makes purchasing decisions.

Table 19. Analyzing The Relationship Between The Person Who Makes

The Monthly Grocery Purchasing Decision And The Person Who Makes Purchasing Decisions

\begin{tabular}{|l||c||c||c||}
\hline $\begin{array}{l}\text { H 10: There is no relationship between the person who makes } \\
\text { the monthly grocery purchasing decision and who makes purchasing } \\
\text { decisions. }\end{array}$ & $\begin{array}{c}\text { Chi-Square } \\
\text { value }\end{array}$ & df & $\begin{array}{c}\text { p } \\
\text { value }\end{array}$ \\
\hline \hline $\begin{array}{l}\text { Person Makes Purchasing Decisions * The Person Who Makes The } \\
\text { Monthly Grocery Purchasing Decision }\end{array}$ & $129,889^{\mathrm{a}}$ & 9 &, 000 \\
\hline
\end{tabular}




\subsection{Analyzing That The Monthly Grocery Purchasing Decision Makes By the Mother In the Household}

The main hypotheses ( $\mathrm{H} 0$ ) of the research is that the purchasing decision of a family's monthly grocery expenses is not made by the mother. Table 20 shows the analyses of the main hypotheses results.

Table 20. Analyzing That The Monthly Grocery Purchasing Decision Makes By the Mother In the Household

\begin{tabular}{|c|c|c|}
\hline $\begin{array}{l}\text { H 0: In the household the monthly grocery purchasing decision is } \\
\text { not made by the mother. }\end{array}$ & $\begin{array}{c}\text { Number of the } \\
\text { Test Subjects }\end{array}$ & $\overline{\mathbf{Z H H}}$ \\
\hline Purchasing Decision Made By The Mother & 219 & 12,0 \\
\hline
\end{tabular}

After the analysis for the main hypothesis, the $\mathrm{ZH}$ value is greater then the value of 1,96 and we reject the $\mathrm{H}_{0}$ hypotheses. After all of the analysis in this research the result is; the monthly grocery purchasing decision is made by the mother in the household.

\section{CONCLUSION}

Our study has concluded that in a turkish family, it is the mother who not only makes and but also carries out the purchasing decision for the monthly grocery expenses of the family.

We found that there is a strong relationship between the gender and the person who makes the purchasing decision for monthly grocery expenses of a family. There is also a relationship between the district the person lives in and the person who makes the purchasing decision for monthly grocery expenses of a family. The income level and the duration of a couple's marriage also have a direct relationship on the person who makes the purchasing decision for monthly grocery expenses of a family. On the other hand, age, education level, the number of children and the number of employed people in the household do not have a relationship with the the person who makes the purchasing decision for monthly grocery expenses of a family.

A consumer's purchasing decision process is quite diffucult to fully understand and measure. Nonetheless, many research efforts have been carried out to determine the person that makes the decisions in the household. As mentioned throughout the article, marketers place a huge importance to determining the family purchasing agents. By doing so, they are able to develop effective, to-the-point sales and promotional strategies and serve their target markets better. We believe that the results of this study will provide turkish and foreign companies the opportunity to understand their target markets better and carry out specific market research and promotional activities aimed at them. In addition, these companies will be in a better position to predict how their consumers will respond to marketing strategies.

\section{REFERENCES}

1. Cemalcilar, İlhan. 1999. Pazarlama (Kavramlar-Kararlar). Beta Basım, İstanbul.

2. Kotler, P., \& Armstrong, G. 1997. Marketing (An Introduction), (4th Edition). Prentice Hall International Inc, New Jersey.

3. Peter, Paul \& J. OLSON.2002. Consumer Behavior and Marketing Strategy (6th Edition). Mc Graw Hill Company, New York.

4. $\quad$ Roberts, Mary Lou. 1981. "Women's changing roles: A consumer behavior perspective." Advances in Consumer Research, vol.8: 590-595.

5. Solomon, Michael. 1996. Consumer Behavior (3rd Edition). Prentice Hall International Inc, New Jersey.

6. Tek, Ömer Baybars. 1999. Pazarlama İlkeleri (Global Yönetimsel Yaklaşım, Türkiye Uygulamaları), (8. Bask1). Beta Basım, İstanbul.

7. http://www.capital.com.tr/c/0211/karar.asp 
Notes 